of visiting the Laboratoire de Physique Nucléaire under the guidance of its director, F. Joliot (who was also an occasional contributor to the discussions), and the French Government's Atomic Energy Establishment at Châtillon, where preparations are far advanced for the erection of a heavy water-uranium oxide plant, and an impressive array of counting equipment of all types is being produced. Châtillon is an old fort in the outer defence girdle of Paris, and the skill with which the dark subterranean rooms have been converted into modern laboratories deserves admiration.

The last day of the congress was free from lectures and offered good opportunities to continue some of the discussions in smaller circles before the final dispersal of the participants of a very successful international meeting.

F. A. Paneth

\section{FAUNA AND FLORA OF PALESTINE}

DALESTINE'S fast diminishing larger fauna is bound to suffer from the Jewish-Arab war; many species of great historic interest may be exterminated, and several, like the gazelle, the geographical races of which have not yet been fully worked out by the modern zoologists in the country, may be among them. Attention was directed to the serious reduction in the numbers of the larger mammals by modern 'hunters' in special surveys reported in the bulletins of the Jerusalem Naturalists' Club in 1946. The difficulty of human food supplies will be a serious threat to the remaining numbers of ibex already on the verge of extinction in the country; and the departure of the Palestine Police Force which alone enforced the British-made game lawsthese prohibited the shooting of ibex, eagles, vultures, kestrels, owls, etc., and imposed certain close seasons and preserved certain forests against goat-grazingwill leave unrestricted the activities of 'hunters' and others. The grazing of these reserves by Beduin goatherds will have a serious effect upon plant life, for the ubiquitous goat is one of the most serious destroyers of flora in the country and a contributory factor to the costly menace of soil erosion.

Bab el Wad, which has been the scene of many recent news reports of a battle on the Jaffa-Jerusalem road, is a pine forest planted by the British authorities, twenty-four kilometres below Jerusalem. It consists mainly of Pinus halepensis and a large summer flora including Varthemia, Centaurea cyanoides, Helichrysum sanguineum, Cistus vilosus, Acanthus syriacus and many Labiates (Bull. 25, Jer. Nat. Club, p. 4), while W. F. W. Harding and E. Hardy collected and photographed in the forest the interesting amaryllid, Pancratium parviflorum, and Narcissus Tazetta, the Palestine iris, and various Crocus, Cyclamen, etc. (J. Roy. Hort. Soc., 71, 3 ; 1946).

The bird-life of Palestine, like the mammals, may see the most immediate threat since the removal of law and order to the larger birds of prey; but the netting of quail, suppressed by the British authorities, will probably be resumed for food, together with the unrestricted shooting of the many wildfowl that visit Lake Huleh and the Jordan Valley. The nightjar is among the birds recorded at Bab el Wad in Hardy's 1946 "Handlist of the Birds of Palestine", and this work pointed out that the great bustard, the Egyptian goose and the Syrian ostrich are already extinct in the country, and the white stork, the lam. mergeier, the imperial eagle and the white-faced duck no longer nest there.
Among the more immediate threats to bird-life in the present emergency will be that to the nesting colony of purple herons at Lake Huleh, the young of which are eaten as food by the Arabs. Other scarce birds likely to be sought to augment the food supplies are the houbara or Macqueen's bustard of the southern and Jordan deserts, which no longer nests in the country, the red-billed chukor partridge of the central hills and the Hey's sand partridge of the semi-deserts. Quail-catching and the shooting of songbirds for food will probably assume the large extent they already reach in Syria. The Hebrew University has shown an active interest in plant and bird conservation, and they and the Arab Scout movement and several private individuals were active supporters of the efforts made by the now defunct Jerusalem Naturalists' Club to conserve the rapidly diminishing fauna of the Holy Land during the last few years of the British mandate, especially at Lake Huleh and in the Jordan Valley; but with the lifting of the central authority, it is to be feared that animal life will suffer from the extensive use of rifle and poison before law and order restore close seasons, game reserves and the control of fire-arms, which are essential if the large mammals like the leopard, ibex, wolf, cheetah and gazelle are to survive.

\section{AFFORESTATION AS A WORLD PROBLEM}

TN a brochure entitled "Forestry and Forest Products-World Situation 1937-1946", issued by the Food and Agriculture Organisation of the United Nations, a graphic exposition of the world's position was produced (see Nature, May 8, p. 710). Prof. H. G. Champion, professor of forestry, University of Oxford, also discussed this theme in a paper entitled "Afforestation as a World Problem" before the Royal Society of Arts on March 17 In this paper he discussed various aspects of forestry and forestry work. As he correctly says, "the majority of us pay little attention to the changes which have taken place in the past in the natural vegetation which covers most of the land not taken up by buildings, roads, gardens, mines or agricultural crops We are barely conscious of the fact that in Britain almost every acre of cultivation and bare land-except on the hill tops and in the fens-has been cleared from the forest which once covered nearly the whole surface. From being a country almost entirely under forest, England has now a lower proportion than any other country in Europe." How often did a predecessor of Prof. Champion's at Oxford, Sir William Schlich, point this out to a deaf Government ?

The respective positions of Western European countries, as shown by figures given by the Food and Agriculture Organisation, are contrasted. The interesting position of the Middle East, contrasted with its position in Biblical and Roman times, is discussed; also that of America, Central and South Africa and Australia. Here the picture is chiefly one of ruthless destruction of the forests, either in the interest of agriculture or stock raising, or due to the habits of the local and introduced populations of annual unchecked firing of the countryside for whatever purpose, and over-grazing. Such actions have produced serious conditions in temperate climates. In the tropics they are devastating. For example, Prof. Champion states that in Nigeria it has been 
estimated that 1,000 square miles of forest are being destroyed by shifting cultivation annually. This type of affairs is proceeding throughout many parts of Africa in British, French, Belgian and Portuguese Colonies. The author contrasts the nature of the vegetation which may clothe the soil when the forest is removed "if, indeed, the soil does get or retain a cover at all". Temperate and tropical conditions are dealt with. Prof. Champion particularly stresses grazing of domestic cattle and the damage caused. "In all but the wet tropical forests, grazing is liable to be second only to direct human action as a forestdestroying agency", a statement which must be known now throughout the world, though still requiring emphatically re-stating. Protection of endangered existing forest areas by closure, reafforesting and so forth are the remedies which are imperative in many parts of the world.

As the report of the Food and Agriculture Organisation stressed, production is not the only aim of the forester. Indirect effects of the presence of the forest on a countryside are also aimed at, and one of the vital ones is protecting the forest or rebuilding a forest to check erosion, shelter agricultural lands and stock and so forth, and the protection of all water catchment areas, including the head waters of streams and rivers.

Einally, Prof. Champion considers the immediate objectives of the larger afforestation undertakings of the world under seven heads: briefly, stabilization of moving sands, increasing local supplies of timber and fuel, stoppage of erosion on hillsides through avalanches and of areas on hills liable to ravine formation, protection by forests or woodland belts of agricultural land and stock and buildings, reafforesting of waste land and growing timber to supply industries for export trade or to maintain or build up stocks at home. These are discussed in some detail in the paper.

\section{SOUTH AFRICAN COUNCIL FOR SCIENTIFIC AND INDUSTRIAL RESEARCH}

$\mathrm{T}$ HE second annual report of the South African Council for Scientific and Industrial Research (Block 1, Central Mint, Pretoria) covering the year ended October 5, 1947, refers to progress in establishing the Council's national laboratories and services as exceeding expectation in many respects, although it will still be several years before all are fully working. Four industrial research associations, covering the leather, fish, paint and sugar-milling industries, are now in being and proposals for a fifth, to deal with the clay and ceramic industries and others interested in silicates, are being discussed. During its first two years the Council has signed contracts for twenty investigations for industrial and other sponsors to a value of $£ 13,968$, and of these seven have been completed. Arrangements for the support of research in universities and similar institutions operated satisfactorily during the year, but it is probable that the Council will have to consider further means of assisting the universities to provide the large number of scientific men and women of high qualifications which will be required.

The work of the Library and Information Division increased greatly during the year. The Library now includes about 70,000 books, pamphlets and reports on all branches of science and technology. A draft guide to authors in the preparation of abstracts has been prepared for the use of South African scientific periodicals the abstracts of which will be distributed overseas. The functions of the three main divisions of the National Building Research Institute have been more sharply defined, and sub-division of the Engineering Division into three sections-engineering, materials, and soil mechanics - is already visualized. The services of the soil mechanics section are already in embarrassing demand. Details of some forty-two projects in which work is already proceeding are given in the report, and among these may be mentioned foundation design for small houses, soil-cement construction, a study of expansive mortar failures in brickwork, standardization of wear-test for flooring, termite-proofing of buildings, comfort standards, tests for the thermal properties of building materials, roof ventilators, ventilation and natural lighting of buildings and a study of native housing.

Considerable progress has been made with the National Physical Laboratory, where the Spectro. graphic Section has made a satisfactory start. Work has already been commenced on the design and construction of instruments for aptitude testing, the measurement of soil pressures, the use of supersonic waves as a bactericide and on general acoustics. The Telecommunications Research Laboratory has measured and studied the characteristics of the ionosphere, and work on the measurement of radio noiselevels was contemplated. Measurements have been made of the propagation of radio waves in the Witwatersrand gold mines, and a micro-wave radar set has been developed for tracking thunderstorms. At the National Chemical Research Laboratory, the Microbiological Section, working at the Onderstepoort Laboratories, has investigated new yeast-like organisms from the rumen ingesta of sheep, and work is proceeding on the determination of degradation products arising from the action of moulds on wattle tannin extract. The fats, waxes, and proteins unit has been concerned with investigations on pilchard oil, the vitamin A content of liver oil from soupfin sharks and on marine fats.

Under the National Bureau for Personnel Research, the three main projects have covered selection and classification tests for operatives in the clothing industry, classification tests for native miners and 'boss-boys', and personnel research for the Union Defence Force. The development of screening and aptitude tests for the engineering branch of the G.P.O. continued during the year. A Liaison Division was formed during the year to provide liaison between the Council's laboratories and industry, including the handling of technical inquiries, visits to industrial firms and the organisation of co-operative research in industry. This Division is also responsible for handling contracts for sponsored research and the overseas scientific liaison offices and missions.

Seven senior bursaries or fellowships were awarded by the Council during the year to enable South Africans of outstanding ability and experience to carry out at least a full year of unencumbered research. Three senior bursaries were also awarded for research in the medical field, and details of these ten awards are given in the report. Twelve bursaries of $£ 200$ a year were also awarded for postgraduate research and five others for postgraduate medical research, and eighteen bursaries of $£ 100$ a year to undergraduate research students. 